\title{
Perception of Seasonal Change in Plant Designs by University Students
}

\author{
Esra Özhanci ${ }^{1}$, Hasan Yilmaz ${ }^{2}$, Sevgi Yilmaz ${ }^{3} *$ \\ ${ }^{1}$ Research Assistant, Ataturk University, Architecture and Design Faculty, Department of Landscape \\ Architecture, 25240, Erzurum, Turkey. \\ ${ }^{2}$ Professor, Ataturk University, Architecture and Design Faculty, Department of Landscape Architecture, \\ 25240, Erzurum, Turkey. \\ ${ }^{3}$ Associate Professor, Ataturk University, Architecture and Design Faculty, Department of Landscape \\ Architecture, 25240, Erzurum, Turkey. *Corresponding author. \\ Tel: +90 442231 2161, e-mail: syilmaz_68@hotmail.com; sevgiy@atauni.edu.tr
}

doi:10.5618/arch.2012.v1.n1.3 || Received: 04-2-2012, Accepted: 28-2-2012, Available online: 06-3-2012

\begin{abstract}
This study is aimed to determine visual perception of seasonal changes. Images involving plant design were chosen from the central campus of Atatürk University. Totally 81 participants were asked to evaluate the images presented to them from the perspective of predetermined parameters. It was found that images taken in autumn received higher scores among others and statistically significant differences were determined between autumn and other seasons. The highest scores were given to images taken on three different scenes $(B, F$ and $J$ ) in autumn, while the images representative of winter taken on the same two scenes ( $F$ and $J$ ) and another different scene $(E)$ received the lowest scores. A group of images taken from one area $(G)$ received very close scores to each other. This area showed no colour effects while the effects of space and depth are dominant in all three seasons.
\end{abstract}

Keywords: Perception; Plant Design; Season; Landscape.

\section{Introduction}

Unplanned and distorted urbanisation caused by the advancement in science, industry and technology caused several physical, psycho-logical and sociocultural problems for people (Akten 2003) [1]. In the majority of the large cities facing urbanisation and industrialisation movements, structural density and other un-planned developments in the parallel of human population increase have caused wrong land use preference; urban areas to lose their links with rural areas; and disappearance of existent open green spaces in urban areas (Y1lmaz et al. 2003) [2].

As the result of the population increase in urban areas and its negative effects on environment, people get away from nature and are obliged to survive their lives among dense concrete structures (Yilmaz et al. 2006) [3]. People must bear in their minds that environmental problems and development are in close relationship while they attempt to provide social and economical development. One of the most important conditions of a meaningful development is to accept the fact that development and environment are not two contrast subjects but they are the complementary of one another. It is the conservation and renovation of natural reserves that form the basis of sustainable development (Öztürk 2005) [4].

Since outdoor leisure activities have several aspects, attractive physical environment is required for these activities (Roovers et al. 2002) [5]. Effective evaluation of design and the creation of design standards require the determination people's landscape preference and desires for the future of landscape (Kearney et al., 2008) [6].

In aesthetical experience involving touching, smelling and voices, visual content is significant and generally dominant (Ode and Fry 2002) [7]. People see and percept the objects in their surroundings, and as the result of this perception they adopt them or not. All these objects carry sensitive loads, in other words, they have formal and symbolic meanings (Kalın 1997) [8].

A comprehensive landscape evaluation requires the integration of ecologic, economic and social values. Landscape view does not only include local or structural parts but also the formal, visual and cultural expression of landscape (Krause 2001) [9].

Even though it is believed that landscape is a physical reality independent of human and which can be 
characterized by various measurements having physical, it has also a reality determined by the sensation of individuals. These sensations can be character-ized or measured in various ways. Perception of beauty may be dependent on the eye of spectators, however, it may be stated that large population masses can share the same landscape perceptions due to their biological heritage or common individual or cultural experiences (Palmer and Hoffman, 2001) [10].

The most important characteristic of environmental aesthetic is its changeability for every moment of life and life dynamics. In this sense, aesthetic is the source of communication between individuality and wholeness, and perception, reaction and stimulation which survive and give energy to life rather than a formal enjoyment. Aesthetic is not only beauty in art, i.e. art philosophy, but involves beauty in nature. Therefore, it is the discipline of perceptions utilised in the evaluation of both natural and artificial elements and science of sensation (Erdogan, 2006) [11].

Landscape view and identity are the most important criteria for its natural and cultural diversity (individual view of elements and local characteristics); and for local and regional landscape to be evaluated, classified and conserved considering possible impacts on them (Krause 2001) [9].

The European Landscape Convention takes landscape into consideration as "the key element of individual and social improvement" and therefore; aims to conserve, manage and plan landscape. World Health Organisation (WHO) defines health as "not only the absence of illness or disability but physical, mental and social wellness in general". The belief that natural elements reduce stress and have favourable effects on patients goes back to the ancient metropolises of Iran, China and Greece (Velarde et al., 2007) [12].

Participant evaluation of landscape scenes based on photographic presentation is used in the landscape visual quality assessment studies (Dearden 1984 [13]; Bergen et al 1995 [14]; Habron 1998 [15]; Clay and Daniel 2000 [16]; Tahvanainen et al 2001 [17]; Clay and Smidt 2004 [18]; Fuante de Val et al 2006 [19]; Müderrisoğlu et al.,2006 [20]; Ozhanci and Yilmaz 2011 [21]).

Various studies (Daniel, 1990 [22]; Kelomaki and Savolainen, 1984[23]; Stamps, 1990[24]) showed considerably large convenience between visual preferences based on landscape images presented and those based on direct experience (Vandenberg and Koole, 2006[25]).
Several studies on the visual effects of the vegetation in urban and rural areas (Daniel and Boster, 1976 [26]; Brown and Daniel, 1984 [27]; Ribe, 1989 [28]; Müderrisoğlu and Eroğlu, 2006[29]) showed that visual perception is effective on management decisions and green area use.

In addition, in several studies, it was observed that naturalness raised the quality value of the areas in landscape quality assessments (Kaplan and Kaplan 1989 [30], Parsons 1991 [31]; Hartig, 1993 [32]). In this respect, urban green areas accepted to be the natural aspects of urban areas should be taken into consideration in planning and management decisions.

The aim of present study is determine how the changes in green tissue in the Central Campus of Atatürk University in three different vegetation periods affect visual and aesthetical perception (preference).

\section{Material and Method}

2.1 Material. Study area is the central campus area of Atatürk University in the city of Erzurum located in the north of East Anatolia Region (Figure 1). The city is the largest in the region with its 360.000 people. The elevation of the campus is $1850 \mathrm{~m}$. Atatürk University comprises of 16 faculties, 4 vocational schools, 8 graduate schools and 15 research and application centres. The university had 33.544 students in 2008 - 2009 educational term. The number of students increases year by year. The areas left for housing, faculties, management, facilities, social structures, dormitory, and green spaces cover a surface area of 33.000 da in the campus. The social area includes banks, cafeterias, centres for leisure activities, cinema, exhibition centres, ceremony and festival areas, sports hall, and a small shopping centre (Anonymous, 2009) [33].

2.2 Method. Landscape visual quality assessment is the active study area in the field of environmental perception (Bergen, et al., 1995 [14]; Habron, 1998 [15]; Meitner, 2004 [34]; Fuante de Val, et al., 2005 [19]; Ozhanc1 and Yilmaz, 2011 [21]). In several studies, landscape characteristics were altered using simulations in perceptual assessment (Clay and Daniel, 2000 [16]; Tahvanainen, et al., 2001[17]; Clay and Smidt, 2004 [18]; Ikemi, 2005 [35]; Müderrisoğlu and Eroğlu, 2006 [29]; Vandenberg and Koole, 2006 [25]).

The method used in the present study is to assess the images presented to the participants in the respect of predetermined parameters. The study includes 4 stages.

2.1.1. Taking images. Images were taken from various parts of the area densely used by pedestrians in three different vegetation periods in order to determine the changes in these periods. The photos taken in spring were not used because the spring period is very short as well as vegetation period in the high altitude $(1850 \mathrm{~m})$ city. The areas where images were taken are directly observed by people (Figure 2). 


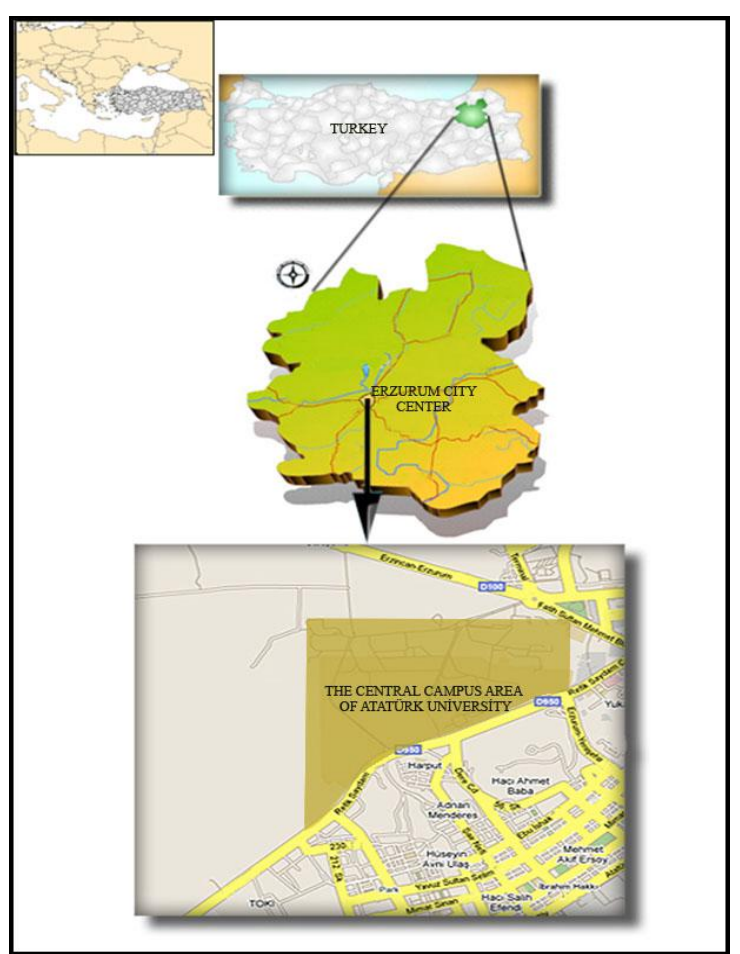

Figure 1. The position of the study area within the states and city.

Images were taken using Nikon D40 digital camera in July (summer), October (autumn) and January (winter) between 11.00 and 17.00. 200 images were obtained for each season and so totally 600 images were taken in all period from the locations. Among them the ideal 27 images were taken into consideration for assessment (Figure 3).

2.1.2. Participants. Participants of the visual assessment were totally 81 students from two departments of the university; 54 from landscape Architecture and 27 from Picture and Graphical Design Department of Fine Arts Faculty, 44 of whom were males and 37 were females and whose mean age was 21 .

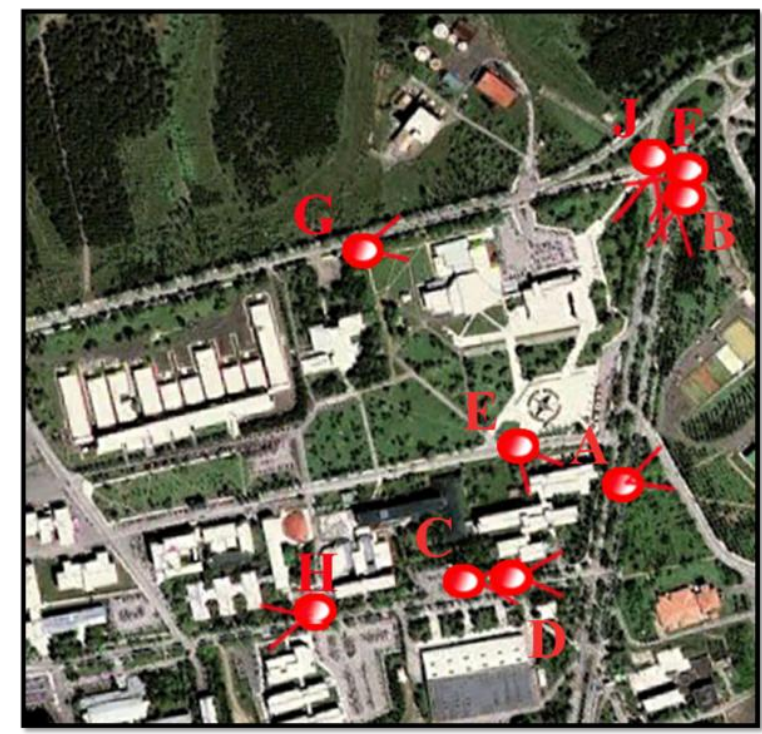

Figure 2. The points taken photographs used in the analysis (A, B, C, D, E, F, G, H, J).

2.1.3. Visual assessment. After informing participants about the content of the study, they were shown 27 images on the same screen and then they were shown individually. The participants were asked to score each image in the range of 0 to 4 . In scoring, " 0 " represents "I do not enjoy at all", "1" "I some enjoyed", "2" "I enjoyed", “3” "I considerably enjoyed" and "4" "I enjoyed very much".

2.1.4. Statistical analysis. SPSS 10.0 statistical software was used to evaluate the results of the scores. In the analysis, one-way variance analysis (ANOVA) was used to compare the averages.

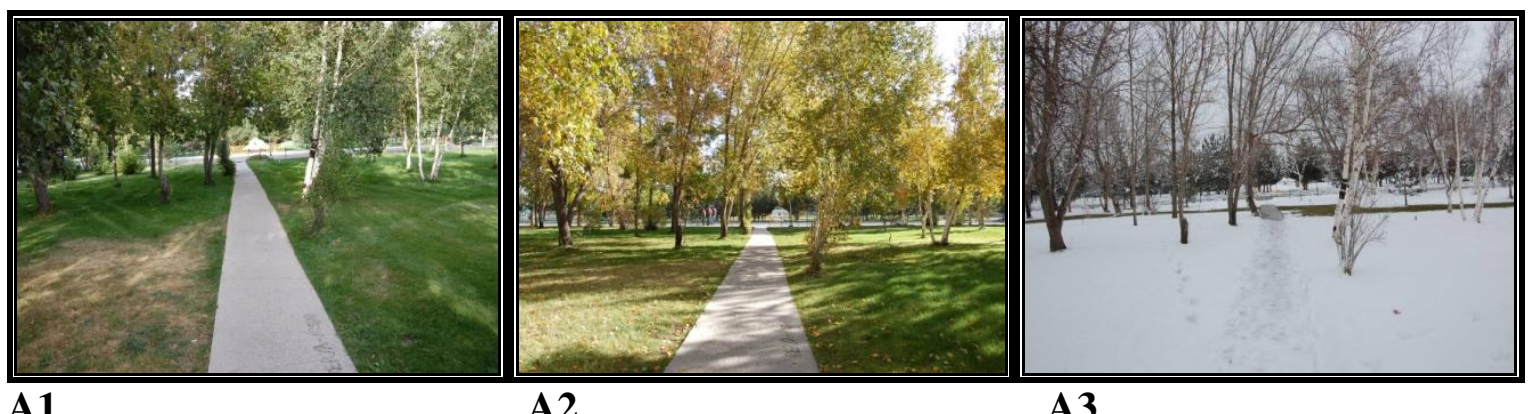

Figure 3. Images used for analysis: summer (left), autumn (medium), winter (right). (to be continued) 

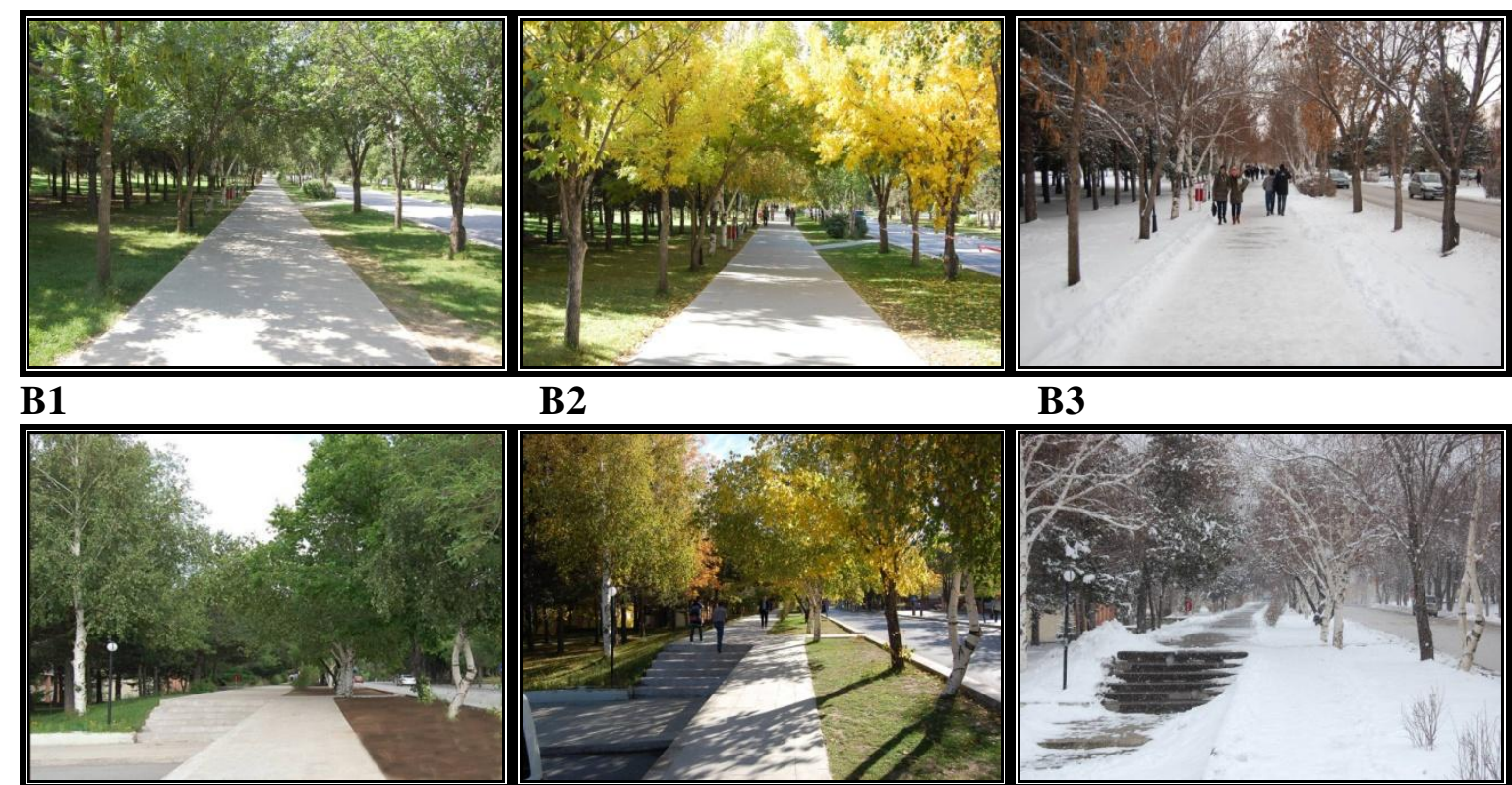

B2

B3
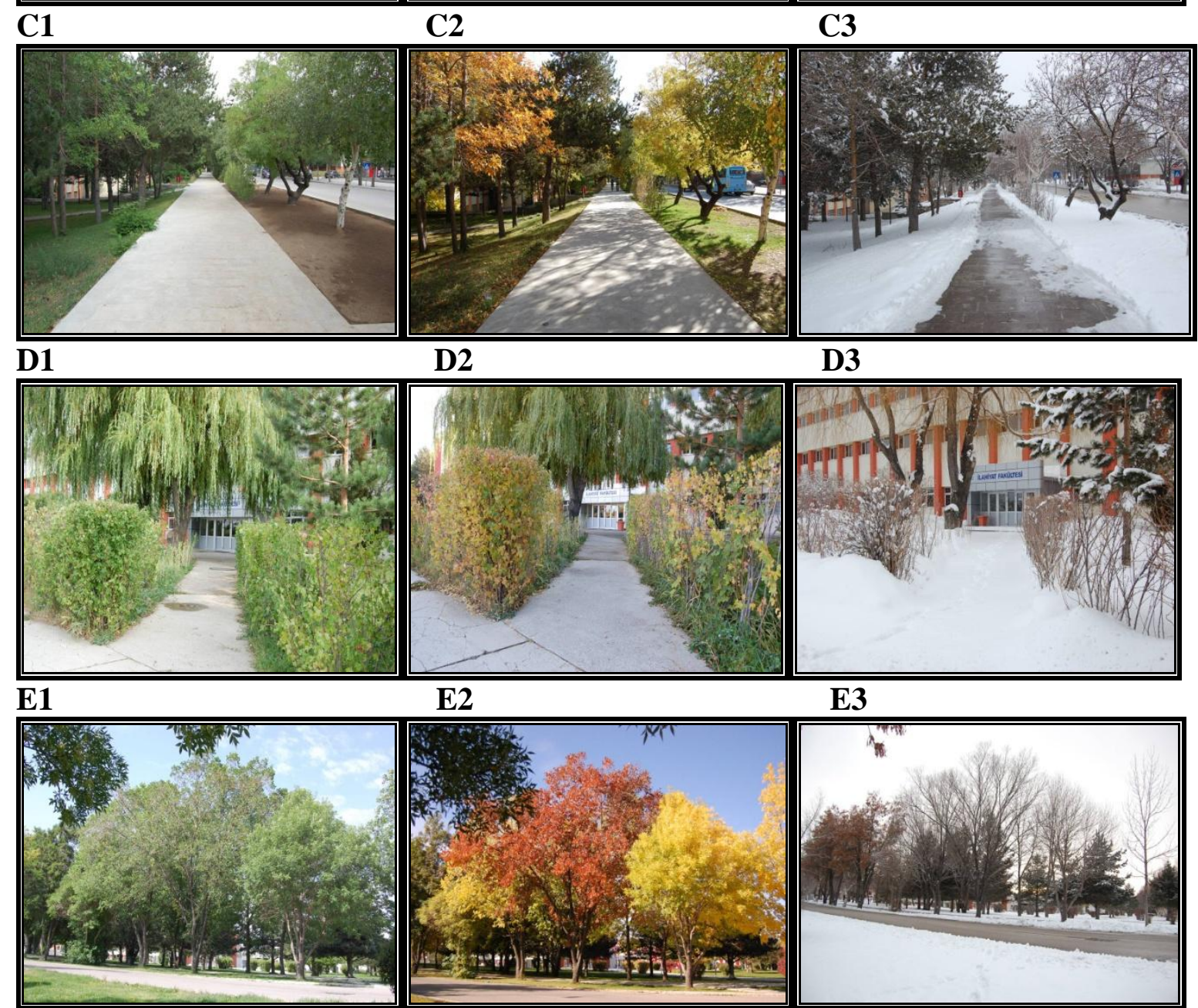

E2

D3
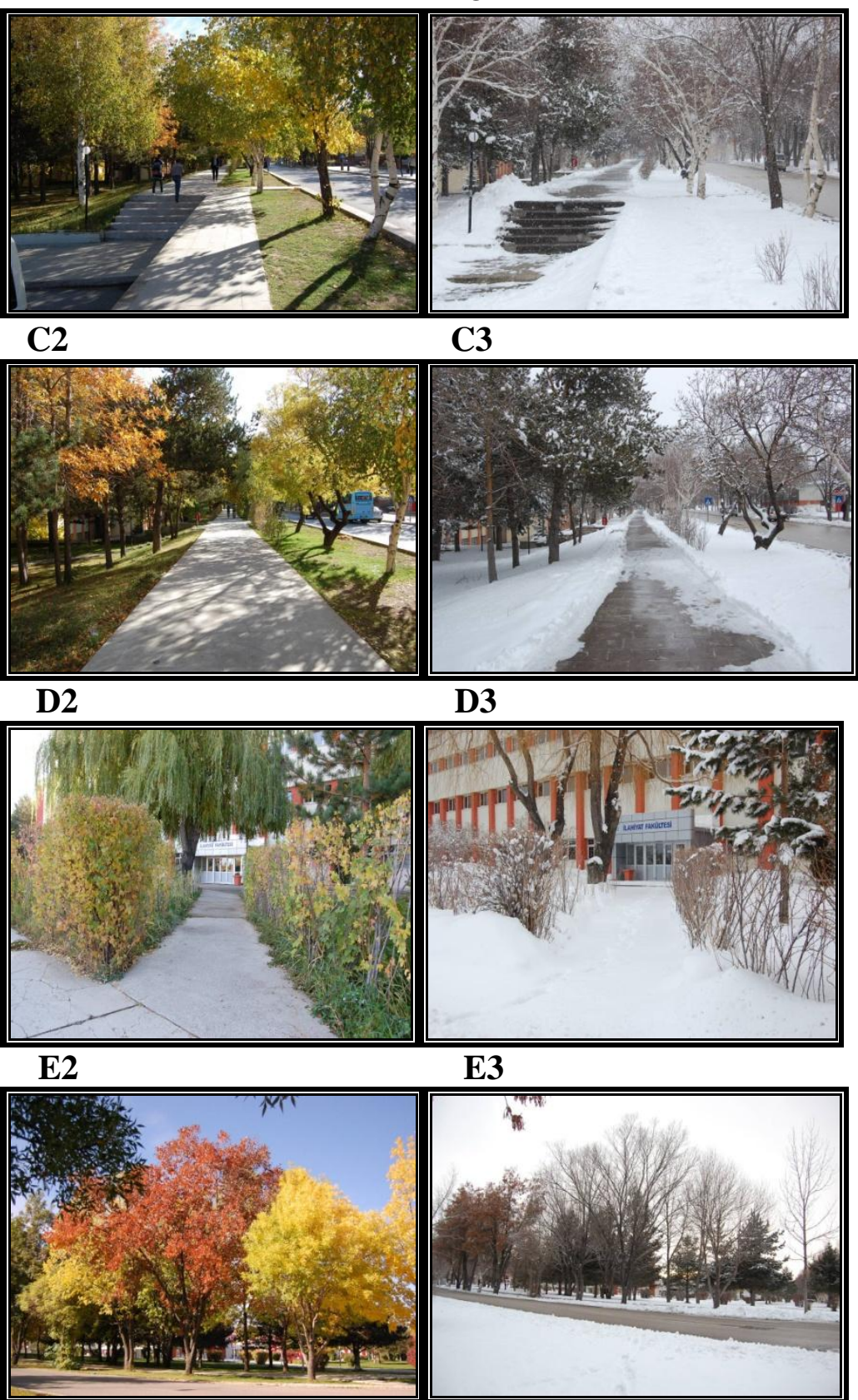

F2

F3

Figure 3. Images used for analysis: summer (left), autumn (medium), winter (right). (to be continued) 

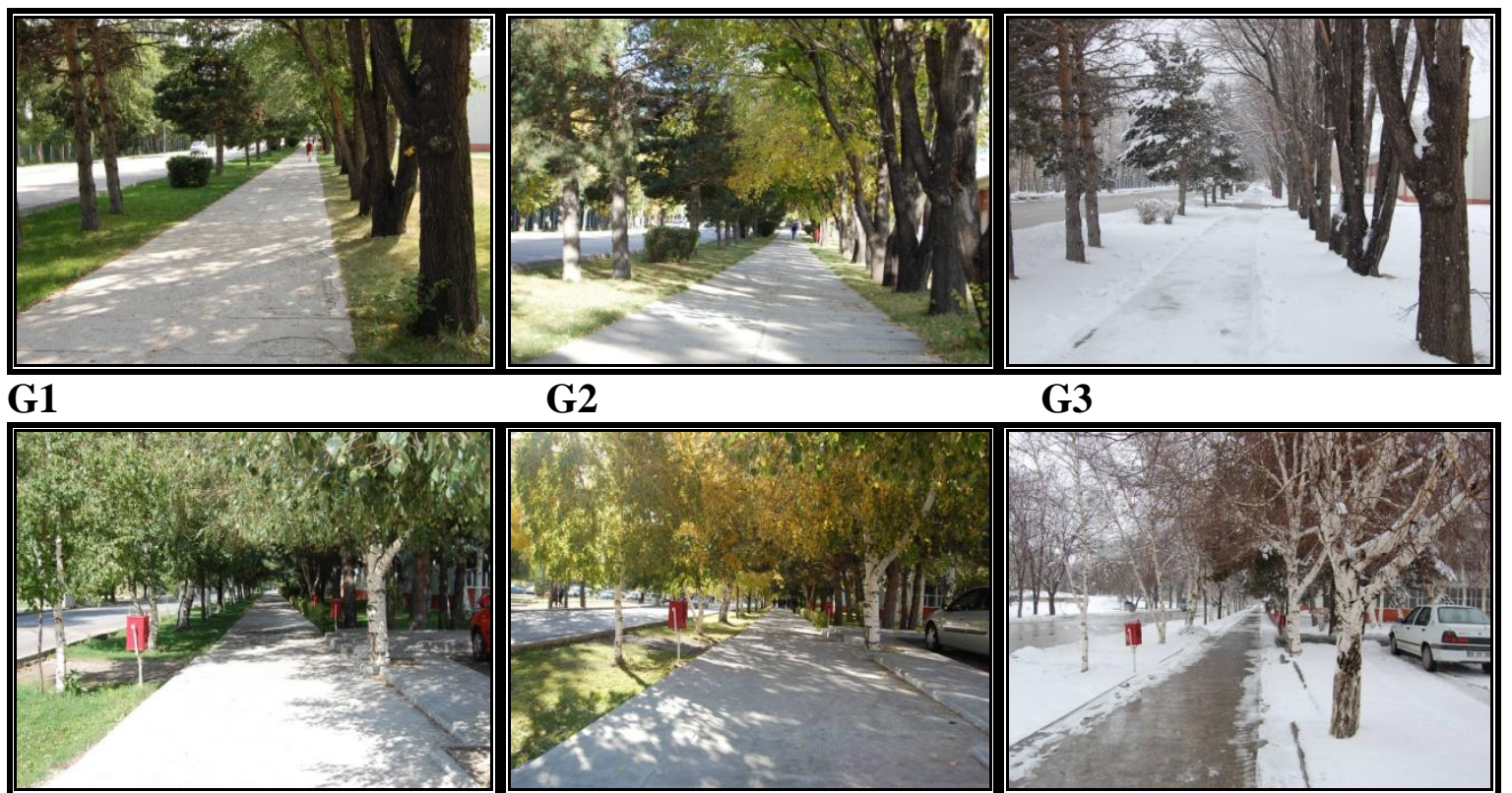

G3

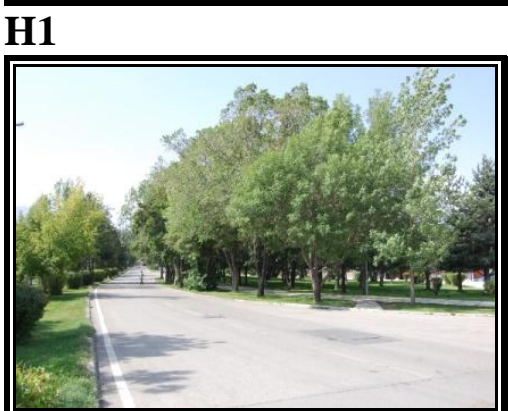

J1
H2

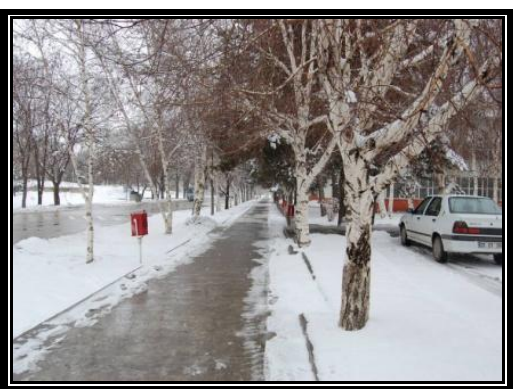

H3

Figure 3. Images used for analysis: summer (left), autumn (medium), winter (right).

\section{Results and discussion}

Table 1 represents the distribution of the scores for each selected image. Based upon the variance values given in Table 1, it could be said that the participants gave close scores to F1 image, in other words, they were very confident in scoring F1, but not for C3. The higher the differences in scores given by the participants, the higher the variance.

The highest scores were given to $\mathrm{J} 2(\mathrm{M}=3.64)$, $\mathrm{F} 2(\mathrm{M}=3.57)$ and $\mathrm{B} 2(\mathrm{M}=3.31)$ while the lowest scores belonged to $\mathrm{F} 3(\mathrm{M}=1.17), \quad \mathrm{E} 3(\mathrm{M}=1.22) \quad$ and $\mathrm{J} 3(\mathrm{M}=1.38)$. It was seen that the highest scores were given to images taken on three different scenes in autumn while the images representative of winter taken on the same two scenes and another different scene received the lowest scores (Figure 4).

Table 2 and Figure 5 represent the distribution of scores for seasons. According to these, the highest scores were given to the images taken in autumn $(M=2.91)$ while the others showed close mean values.
Table 3 shows the results of one-way analysis of variances (ANOVA). The ANOVA was used to test for differences among the independent means (seasons). The first column of the ANOVA table describes the source of variance. The second column is the sum of squares for each of the estimates of variance. The third column gives the degrees of freedom for each estimate of variance. The fourth column gives the estimates of variance in where each mean square is calculated by dividing the sum of square, which is the sum of the squared differences of each observation from the overall mean, by its degrees of freedom. The fifth column gives the F ratio which is calculated by dividing mean square between-groups by mean square within-groups, and the last column gives the significance of the $\mathrm{F}$ ratio. Differences between groups (seasons) were found statistically significant at $\mathrm{p}<0.001$ significance level. This indicated that the seasons had great influences on scoring. 
Table 1. Distribution of the scores for each selected image.

\begin{tabular}{|c|c|c|c|c|}
\hline Scene no & $\operatorname{Sum}(\mathbf{S})$ & Mean(M) & Std. deviation & $\mathbf{N}$ \\
\hline $\mathrm{A} 1$ & 132 & 1.63 & .99 & 81 \\
\hline $\mathrm{A} 2$ & 199 & 2.46 & .85 & 81 \\
\hline A3 & 131 & 1.62 & 1.23 & 81 \\
\hline $\mathrm{B} 1$ & 172 & 2.12 & .78 & 81 \\
\hline $\mathrm{B} 2 * *$ & 268 & 3.31 & .97 & 81 \\
\hline B3 & 163 & 2.01 & 1.21 & 81 \\
\hline $\mathrm{C} 1$ & 160 & 2.00 & 1.09 & 81 \\
\hline $\mathrm{C} 2$ & 230 & 2.84 & .93 & 81 \\
\hline C3 & 188 & 2.32 & 1.52 & 81 \\
\hline D1 & 151 & 1.86 & 1.05 & 81 \\
\hline D2 & 258 & 3.19 & .90 & 81 \\
\hline D3 & 129 & 1.59 & 1.18 & 81 \\
\hline E1 & 216 & 2.67 & 1.13 & 81 \\
\hline E2 & 156 & 1.93 & 1.10 & 81 \\
\hline E3* & 99 & 1.22 & 1.17 & 81 \\
\hline F1 & 154 & 1.92 & .81 & 81 \\
\hline $\mathrm{F} 2 * *$ & 289 & 3.57 & .84 & 81 \\
\hline F3* & 95 & 1.17 & 1.02 & 81 \\
\hline G1 & 197 & 2.43 & 1.02 & 81 \\
\hline $\mathrm{G} 2$ & 212 & 2.62 & .97 & 81 \\
\hline G3 & 178 & 2.20 & 1.30 & 81 \\
\hline $\mathrm{H} 1$ & 172 & 2.15 & .92 & 81 \\
\hline $\mathrm{H} 2$ & 215 & 2.65 & .99 & 81 \\
\hline $\mathrm{H} 3$ & 116 & 1.43 & 1.15 & 81 \\
\hline J1 & 189 & 2.33 & 1.01 & 81 \\
\hline $\mathrm{J} 2 * *$ & 291 & 3.64 & .97 & 81 \\
\hline $\mathrm{J} 3 *$ & 112 & 1.38 & 1.03 & 81 \\
\hline
\end{tabular}

**highest rated images, *lowest rated images

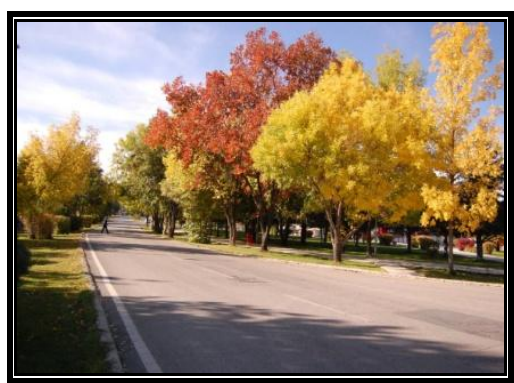

$\mathbf{J} 2$

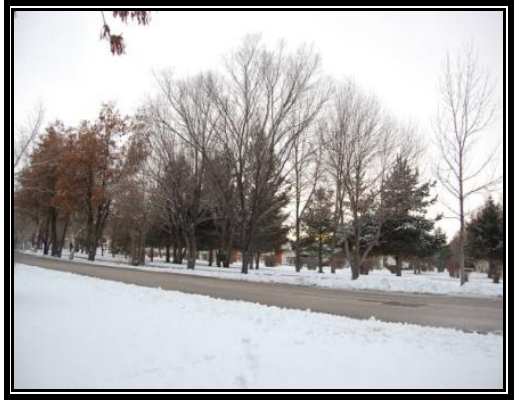

F3

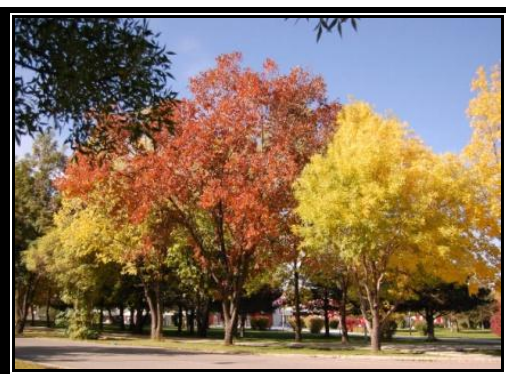

F2

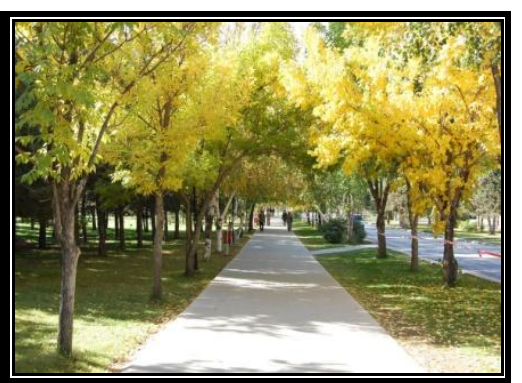

B2

(a)

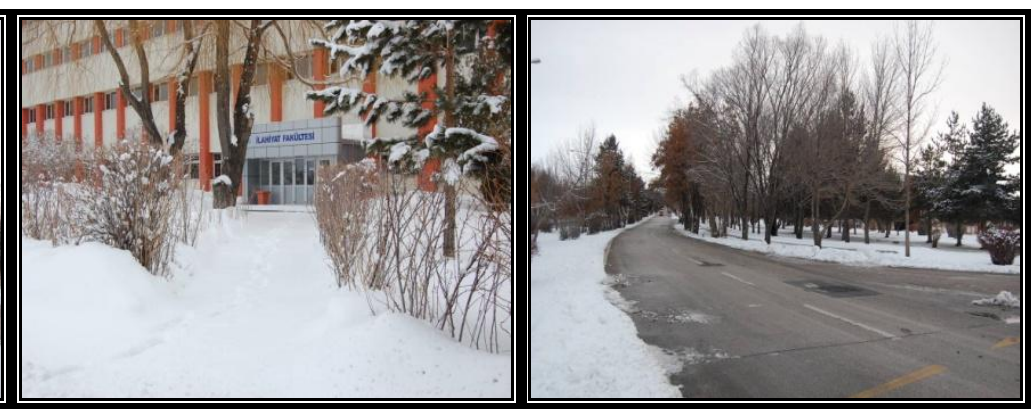

$\mathbf{J 3}$

(b)

Figure 4. (a) highest rated images (J2, F2 and B2) ; (b) lowest rated images (F3, E3 and J3). 
Table 2. Distribution of seasonal scores.

\begin{tabular}{lll}
\hline & Mean $(\mathbf{M})$ & Std. deviation \\
\hline Autumn & 2.91 & 1.08 \\
Summer & 2.13 & 1.02 \\
Winter & 1.66 & 1.27 \\
\hline
\end{tabular}

Table 3. ANOVA test of images taken in three different seasons as the result of analysis between groups and within groups.

\begin{tabular}{llllll}
\hline $\begin{array}{l}\text { Source } \\
\text { of } \\
\text { variance }\end{array}$ & $\begin{array}{l}\text { Sum of } \\
\text { Squares }\end{array}$ & & $\begin{array}{l}\text { Mean } \\
\text { Square }\end{array}$ & F & $\begin{array}{l}\text { Signi- } \\
\text { ficant }\end{array}$ \\
\hline $\begin{array}{l}\text { Between } \\
\text { Groups }\end{array}$ & 579.8 & 2 & 289.9 & 227.4 & .000 \\
& & & & & \\
$\begin{array}{l}\text { Within } \\
\text { Groups }\end{array}$ & 2778.9 & 2180 & 1.3 & & \\
\hline
\end{tabular}

\section{Conclusions}

In the present study, main aim was to determine the visually most preferred season by asking the question "Are the seasonal changes in plant materials used in urban areas an effective factor on the preference of people?" As the result of the study, autumn was found to be the visually most preferred season when considered the scores received by the images taken in this season and their statistical differences.

When considered the images received the highest scores, it was seen that their common characteristics were their colour diversity, which prevented images from monotony and caused them to be harmoniously more elaborated and attractive. According to Kaplan and Kaplan (1982), harmony and clarity play major role in the assessment of the landscape structure (Fuente de Val et al. 2005) [19].

In addition, Hunziker and Kienast (1999) [36] defined a significant relationship between diversity and image scores by reaching the thought that diversity and heterogeneity are the parameters which can be linked to environmental perception of human most easily among other perceptual parameters. They also stated that there is a positive relationship between harmony and image score. In a similar way, Clay and Smidt (2004) [15] used the parameter of diversity in the visual assessment and showed its close relationship with preference.

Images belonging to group $\mathrm{G}(\mathrm{G} 1, \mathrm{G} 2, \mathrm{G} 3)$ received very close scores to each other. These images showed no difference for colour effect while the effects of space and depth are dominant in all three seasons.

Among the images belonging to groups A, B, C and $\mathrm{D}$, summer and winter images received close scores while autumn scores were higher. Autumn might have contributed to the colour diversity of these images while in summer and winter images are dominated by monotone colours.

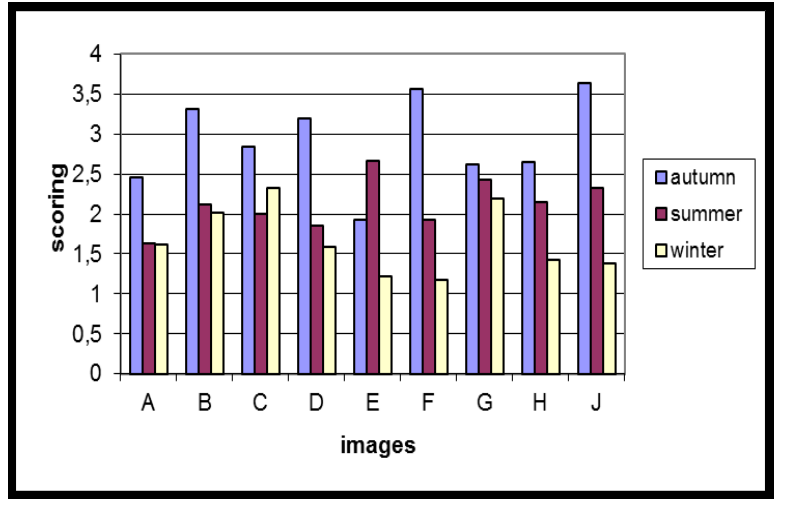

Figure 5. Histogram of score distribution of images in the studied seasons.

Since universities provide individuals scientific, academic and educational areas, their environment is very important for people to perform these activities. Natural and cultural identity of environment is closely related to the clarity of individual mind. Grahn and Stigsdotter (2004) [37] mentioned the favourable effects of spending time in green areas on human psychology. Ulrich (1979) conducted a series of experiments on the effect of viewing nature and natural landscape on human psychology by investigating the effect of visual landscape on emotional condition of stressful students after final examinations. According to results, it was stated that the students viewing natural scenes faced less stress while those who watched built scenes had more stress (Özgüner 2004) [38].

In the light of mentioned facts, we suggest,

- The areas which can positively contribute to the human motivation should be considered and designed in urban areas (in especially densely used ones by youths and workers),

- In plant designing, whole year effects of evergreens should be taken into consideration and plant materials should be chosen to enforce the colour effect of the areas to be designed,

- Under harsh climatic conditions, like the city of Erzurum, where plant diversity is less than other areas, convenient plants with autumn colour effects should be preferred and colour diversity and harmony should be provided using alternative elements.

Living areas should be evaluated for rural and urban life quality and landscape designs should be performed considering these elements. In plant design, both aesthetical and functional concerns should be considered. 


\section{References}

[1] Akten, M., Determination of the existing potentials of some recreational areas in Isparta province, Süleyman Demirel University Journal of Forestry Faculty, 2003, (2), 115-132.

[2] Yilmaz, H.; Yilmaz, S.; Yildiz, N.D., Determination of the Recreational Demands And Tendencies of the People in the City Center of Kars. Atatürk University Journal of Agricultural Faculty, 2003, 34 (4), 353-360.

[3] Yilmaz, H.; Turgut, H.; Demircan, N., Determination of people's aspects about hobby gardens in Erzurum city. Süleyman Demirel University Journal of Forestry Faculty, 2006, A(1), ISSN: 1302-7085, 96-110.

[4] Öztürk, S., Examination of recreational source values in Kastamonu-Bartın Kure Mountains National Park, Süleyman Demirel University Journal of Forestry Faculty, 2005, A(2), ISSN: 1302-7085, 138-148.

[5] Roovers, P.; Hermy, M.; Gulinck, H., Visitor profile, percptions and expectations in forests from a gradient of increasing urbanisation in central Belgium. Landscape and Urban Planning, 2002, 59, 129-145.

[6] Kearney, A.R.; Bradley, G.A.; Petrich, C. H.; Kaplan, R.; Kaplan, S.; Colebank, D.C., Public perception as support for scenic quality regulation in a nationally treasured landscape. Landscape and Urban Planning. 2008, 87, 117-128.

[7] Ode, A.K.; Fry, G.L.A., (). Visual aspects in urban woodland management. Urban Forestry and Urban Greening, 2002, 1 (1), 15-24.

[8] Kalın, A., Symbolic value of plants: A research on evocative plants of buildings and places in different functions. Ms. Thesis KTÜ Graduate school of natural and applied sciences Landscape Architecture department, 1997, Trabzon.

[9] Krause, C.L., Our visual landscape: Managing the landscpe under special consideration of visual aspects. Landscape and Urban Planning, 2001, 54, 239-254.

[10] Palmer, J.F.; Hoffman, R.E., Rating reliability and representation validty in scenic landscape assessments. Landscape and Urban Planning, 2001, 54,149-161.

[11] Erdoğan, E., Environment and city aesthetics.Journal of ZKÜ Bartın Forestry Faculty, 2006, 8 (9) , 68-77.

[12] Velarde, M. D.; Fry, G.; Tveit, M., Health effects of viewing landscapes- Landscape types in environmental psychology. Urban Forestry and Urban Greening, 2007, 6, 199-212.
[13] Dearden, P., Factors influencing landscape preferences: An empirical investigation . Landscape and Planning, 1984, 11(4), 293-306.

[14] Bergen, S. D.; Ulbricht C. A.; Fridley J. L.; Ganter M. A., The validity of computer-generated graphic images of forest landscape. Journal of Environmental Psychology, 1995,15(2), 135-146.

[15] Habron, D., Visual perception of wild land in Scotland. Landscape and Urban Planning, 1998,42,45-56.

[16] Clay, G.R.; Daniel T.C., Scenic landscape assessment: the effects of land management jurisdiction on public perception of scenic beauty. Landscape and Urban Planning, 2000, 49, 1-13.

[17] Tahvanainen, L.; Tyrvainen L.; Ihalainen M.; Vuorela N.; Kolehmainen, O.,. Forestmanagement and public perceptions -visual versus verbal information. Landscape and Urban Planning, 2001, $53,53-70$.

[18] Clay, G.R.; Smidt, R.K., Assessing the validity and reliability of descriptor variables used in scenic highway analysis. Landscape and Urban Planning, 2004, 66, 239-255.

[19] Fuante de Val, G.; Atauri, A.J.; Lucio J.V., Relationship between landscape visual attributes and spatial pattern indices: A test study in Mediterranean- climate landscapes. Landscape and Planning, 2006, 77(4), 393-407.

[20] Müderrisoğlu, $\quad$ H.; Eroğlu, E.; Özkan, S.; $\mathrm{Ak}, \mathrm{K}$., Visual perception of tree forms. Building and Environment, 2006, 41(6), 796-806.

[21] Özhanc1, E.; Y1lmaz, H., Evaluation of Recreation Areas for Visual Landscape Quality; Sample of Erzurum, Turkey. Iğdır Univ. J. Inst. Sci. \& Tech. 2011, 1(2): 67-76.

[22] Daniel, T.C., Measuring the quality of the natural environment: A psychophysical approach. American Psychol. 1990, 45, 633-637.

[23] Kellomaki, S.; Savolainen, R., The scenic value of the forest landscape as assessed in the field and the laboratory. Landscape Planning, 1984, 11, 97107.

[24] Stamps, A.E., Use of photographs to simulate environments: a meta-analysis. Perceptual Motor Skills, 1990, 71, 907-913.

[25] Van den Berg, A.E.; Koole S.L., New wilderness in the Netherlands: An investigation of visual preferences for nature development landscapes. Landscape and Urban Planning, 2006, 78(4), 362372.

[26] Daniel, T.C; Boster, R.S., Measuring landscape esthetics: the scenic beauty estimation method. USDA forest service research paper, 1976, RM167. 
[27] Brown, T.C.; Daniel T.C., Modeling forest scenic beauty: concepts and application to ponderosa pine. USDA forest service research paper, 1984,RM-256.

[28] Ribe, R., The aesthetics of forestry: what has empirical preferences research taught us? Environmental Management, 1989, 13, 55-74.

[29] Müderrisoğlu, H.; Eroğlu, E., Differences in visual perception of some coniferous trees under snow load. Süleyman Demirel University Journal of Forestry Faculty, 2006, A(1), ISSN: 1302-7085, 136-146.

[30] Kaplan, R.; Kaplan, S., The Experience of Nature: A Psychological Perspective. Cambridge University, Cambridge U.K. 1989.

[31] Parsons, R.,. the potential influences of environmental perception on human health. J.Environ. Psychol. 1991, 11, 1-23.

[32] Hartig, T., Nature experience in transactional perspective. Landscape and Urban Planning, 1993, $25,17-36$.
[33] Anonymous, 2009.

http://www.atauni.edu.tr/misyon.htm

[34] Meitner, M.J., Scenic beauty of river views in the Grand Canyon: relating perceptual judgments to locations. Landscape and Urban Planning, 2004, 68, 3-13.

[35] Ikemi, M., The effects of mystery on prefernce for residential façades. Journal of Environmental psychology, 2005, 25, 167-173.

[36] Hunziker, M.; Kienast, F., Potential impacts of changing agricultural activities on scenic beauty $-\mathrm{a}$ prototypical technique for automated rapid assessment. Landscape Ecology, 1999, 14, 161176.

[37] Grahn P.; Stigsdotter, A.U., Landscape planing and stres, Urban Forestry, 2004, 2(1), 1-18.

[38] Özgüner, H., Psychological well being and health benefits derived from contact with nature. Süleyman Demirel University Journal of Forestry Faculty, 2004, A(2), ISSN: 1302-7085, 97-107. 